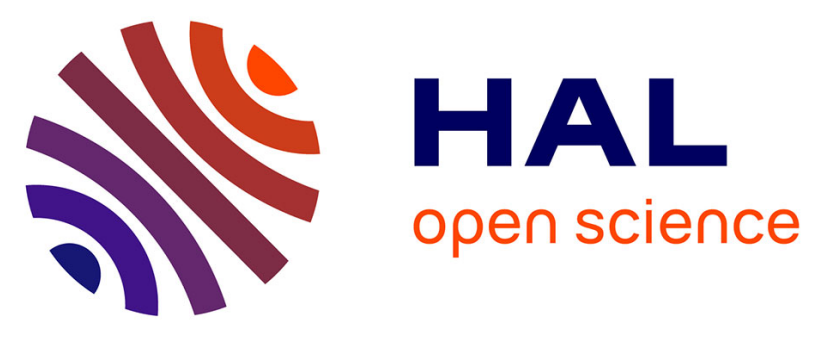

\title{
Recent Geochemical and Grain Size Distribution of Terrestrial Sediment in Coastal Area from the Watershed of Medjerda River, Gulf of Tunis
}

Thouraya Benmoussa, Oula Amrouni, Laurent Dezileau, Yu Fisjak, Domenico Chiarella, Saadi Abdeljaouad

\section{To cite this version:}

Thouraya Benmoussa, Oula Amrouni, Laurent Dezileau, Yu Fisjak, Domenico Chiarella, et al.. Recent Geochemical and Grain Size Distribution of Terrestrial Sediment in Coastal Area from the Watershed of Medjerda River, Gulf of Tunis. Mabrouk Boughdiri; Beatriz Bádenas; Paul Selden; Etienne Jaillard; Peter Bengtson; Bruno R.C. Granier. Paleobiodiversity and Tectono-Sedimentary Records in the Mediterranean Tethys and Related Eastern Areas - Proceedings of the 1st Springer Conference of the Arabian Journal of Geosciences (CAJG-1), Tunisia 2018, Springer, pp.347-351, 2019, Advances in Science, Technology \& Innovation, 978-3-030-01451-3. 10.1007/978-3-030-01452-0_83 . hal-02404904

\section{HAL Id: hal-02404904 \\ https://hal.umontpellier.fr/hal-02404904}

Submitted on 11 Dec 2019

HAL is a multi-disciplinary open access archive for the deposit and dissemination of scientific research documents, whether they are published or not. The documents may come from teaching and research institutions in France or abroad, or from public or private research centers.
L'archive ouverte pluridisciplinaire HAL, est destinée au dépôt et à la diffusion de documents scientifiques de niveau recherche, publiés ou non, émanant des établissements d'enseignement et de recherche français ou étrangers, des laboratoires publics ou privés. 


\title{
Recent Geochemical and Grain Size Distribution of Terrestrial Sediment in Coastal Area from the Watershed of Medjerda River, Gulf of Tunis
}

\author{
Thouraya Benmoussa, Oula Amrouni, Laurent Dezileau, Gil Mahé, Domenico Chiarella, and \\ Saâdi Abdeljaouad
}

\begin{abstract}
The geochemical and grain size analysis were carried out on surface and down core sediments from the present-day alluvial-coastal plain of the Medjerda River, Gulf of Tunis, Tunisia. The aim of this paper is to characterize the geochemical and grain size distribution of sediments and its relationship with the hydrodynamics extreme events occurring during the last century. Using a multi proxy approach, six turbidities layers have been identified in down core sediment (i.e. TL-1, TL-2, TL-3, TL-4, TL-5, TL-6, TL-7 and TL-8) characterized by multimodal grain size distribution. The terrestrial sediment which feeds the northern coastal of the Gulf of Tunis is characterized by very fine-grained sediment (clay and silt). The geochemical signature shows a highly concentration of $\mathrm{Rb}, \mathrm{Ti}, \mathrm{Zn}$ and $\mathrm{Pb}$. The Medjerda River is the mainly source of silts and clay sediment. Besides, the mining pollution ( $\mathrm{Zn}$ and $\mathrm{Pb}$ ) is relatively strong in the coastal area, especially during the great floods events of Medjerda watershed
\end{abstract}

T. Benmoussa $(\bowtie) \cdot S$. Abdeljaouad

Laboratory of Energetic, Mineral Resources and Environment, Faculty of Sciences of Tunis, University of Tunis El-Manar,

Tunis, Tunisia

e-mail: benmoussa_thouraya@yahoo.fr

O. Amrouni

Laboratory of Marine Environment, National Institute of Marine

Sciences and Technologies, Salammbô, Tunisia

L. Dezileau

Laboratoire Morphodynamique Continentale et Côtière,

University of Caen, Caen, France

G. Mahé

UMR HydroSciences Montpellier/IRD, Montpellier, France

D. Chiarella

University of London, Royal Holloway, Egham, TW20 0EX, UK recorded in the 1953; 1957; 1969 and 1973. Even during high frequency events, the sediments are devoid of any coarse fraction.

\section{Keywords \\ Coastal $\bullet$ Medjerda river $\cdot$ Extreme floods \\ Turbidities layers $\cdot$ Mining pollution}

\section{Introduction}

Rivers are sources of water for social and economic development with the alluvial plain of offering a relatively flat area for urban and agricultural activities. However, human societies have to deal with the fact that the flow of water in river basins is never constant. An often high flow of water during the extreme floods events is one of the more types of natural disasters. Moreover, the sediment leaching from the watershed causes coastal contamination through urban, industrial and agricultural discharges. Rivers are considered as the principal sediment delivery toward the marine environments and are closely depended on the climatic and the human pressure [1, 2]. The Medjerda River basin in NE-Tunisia is one of the largest basins in the northern zone of Africa. It is located in the northern bay of the Gulf of Tunis between $37^{\circ} 10^{\prime} \mathrm{N}-10^{\circ} 16^{\prime} \mathrm{E}$ and $37^{\circ} 55^{\prime} \mathrm{N}-10^{\circ} 18^{\prime} \mathrm{E}$. The aim of the present study is to characterize the recent geochemical and grain size distribution of the terrestrial sediment in coastal area.

\section{Settings and Analytical Methods}

We collected short cores sediment core (CEM-1; $168 \mathrm{~cm})$ at the new delta of Medjerda River. Six surface samples were collected at the coastal area (MED-2, MED-3, MED-North, O10, and O20) and the sediment deposits of the riverbanks of Medjerda (MED-1). The grain size analysis was carried 




Sand
Fine
Clay sand Shell
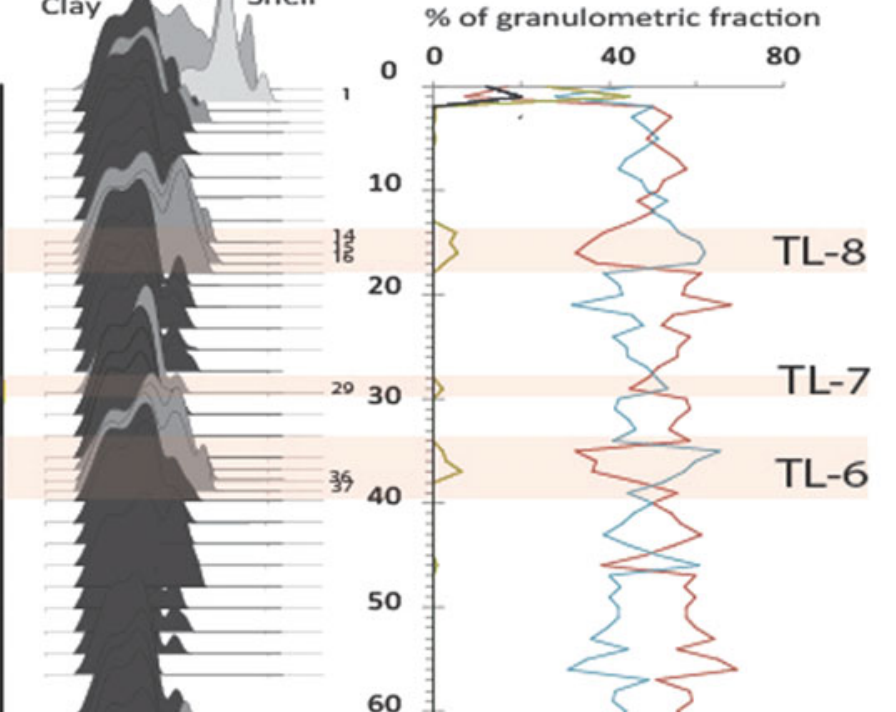
out by using the Backman Coulter LS 13320. A semi-quantitative geochemical analysis was performed by using the X-ray fluorescence (XRF) mobile. To flow the trace terrestrial sediment geochemically, the $\mathrm{Zn} / \mathrm{Fe} ; \mathrm{Pb} / \mathrm{Fe}$ and $\mathrm{Zr} / \mathrm{Fe}$ inter-elements ratios have been used. This method provides the advantage to be insensitive to dilution and matrix effects [3].

\section{Results}

\subsection{Spatial and Temporal Grain Size Distribution and Turbidities Layers Identification}

\subsubsection{Litho Stratigraphic and Sedimentological Description of Turbidity Layers}

The results of the grain size distribution of down core sediment are summarized in the Fig. 1. The CEM-1 core sediment shows litho stratigraphic and grain size variability. The down core was roughly divided, from bottom to top, into three major units of granulometric facies: fine sand, silt-clay and medium sand/shell. In the silt-clay facies, 6 coarser turbidities layers are identified from TL-1, TL-2, TL-3, TL-4, TL-5, TL-6, TL-7 and TL-8. These TL layers consist of fine-grained sediments showing multimodal grain size distribution.

\subsubsection{Spatial Grain Size Distribution}

The Sand/Shell facies of CEM-1(0 and $1 \mathrm{~cm}$ depth $)$ is characterized by multimodal grain size distribution. In particular, it is composed of medium sand (200-315 $\mu \mathrm{m})$ and shells $(1200 \mu \mathrm{m})$. The riverbanks deposits (MED-1) display medium sand with no occurrence of shell fractions. The sandy beach sediment (MED-2, MED-3 and MED-Nord) is characterized by unimodal grain size distribution with medium sand (250-315 $\mu \mathrm{m})$. The submarine samples (O10 and $\mathrm{O} 20$ ) collected in the near shore zone display a unimodal grain size distribution with fine sand (100-125 $\mu \mathrm{m})$.

\subsection{Geochemical Tracer's Evolution of Sediment Sources}

The geochemical evolution of sediment in the different environments is summarized in the Fig. 2 . The $\mathrm{Rb}$ and $\mathrm{Ti}$ show strongly concentration in the river banks sediment, Flood deposits of Medjerda River and deltaic deposits (silt-clay unit of CEM-1. $\mathrm{Pb}$ and $\mathrm{Zn}$ have distinguished peaks at $125 \mathrm{~cm} ; 35.56$ and $259.36 \mathrm{ppm}$ at $73 \mathrm{~cm}: 14.98$ and $95.45 \mathrm{ppm}$ at $68 \mathrm{~cm}$ : 98.96 and $174.91 \mathrm{ppm}$ at $37 \mathrm{~cm}$ : 130.51 ad $185.13 \mathrm{ppm}$ at $29 \mathrm{~cm}$ depth: 31.23 and $103.03 \mathrm{ppm}$ and $16 \mathrm{~cm}$ depth: 20.86 and $110.94 \mathrm{ppm}$, respectively. The $\mathrm{Zr}$ shows a similar evolution compared to the calcium $(\mathrm{Ca})$. in addition, the $\mathrm{Zr}$ is significantly
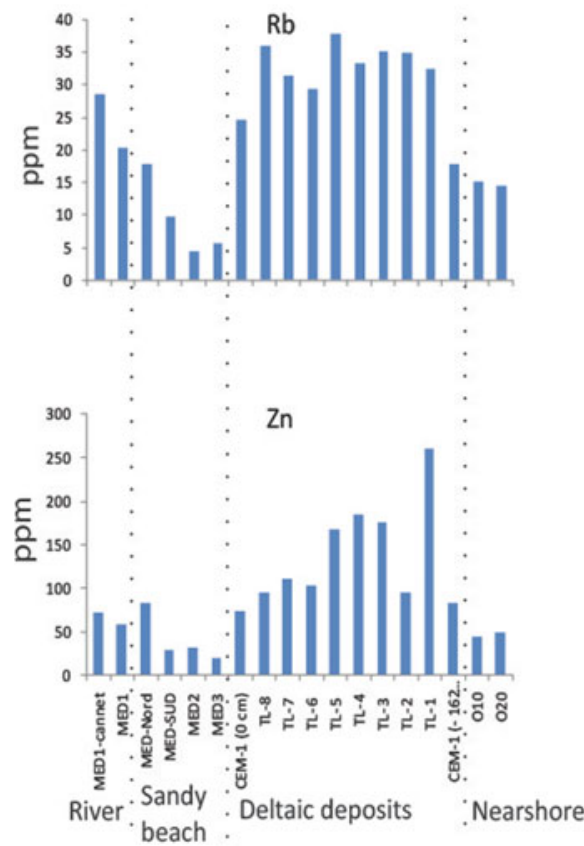
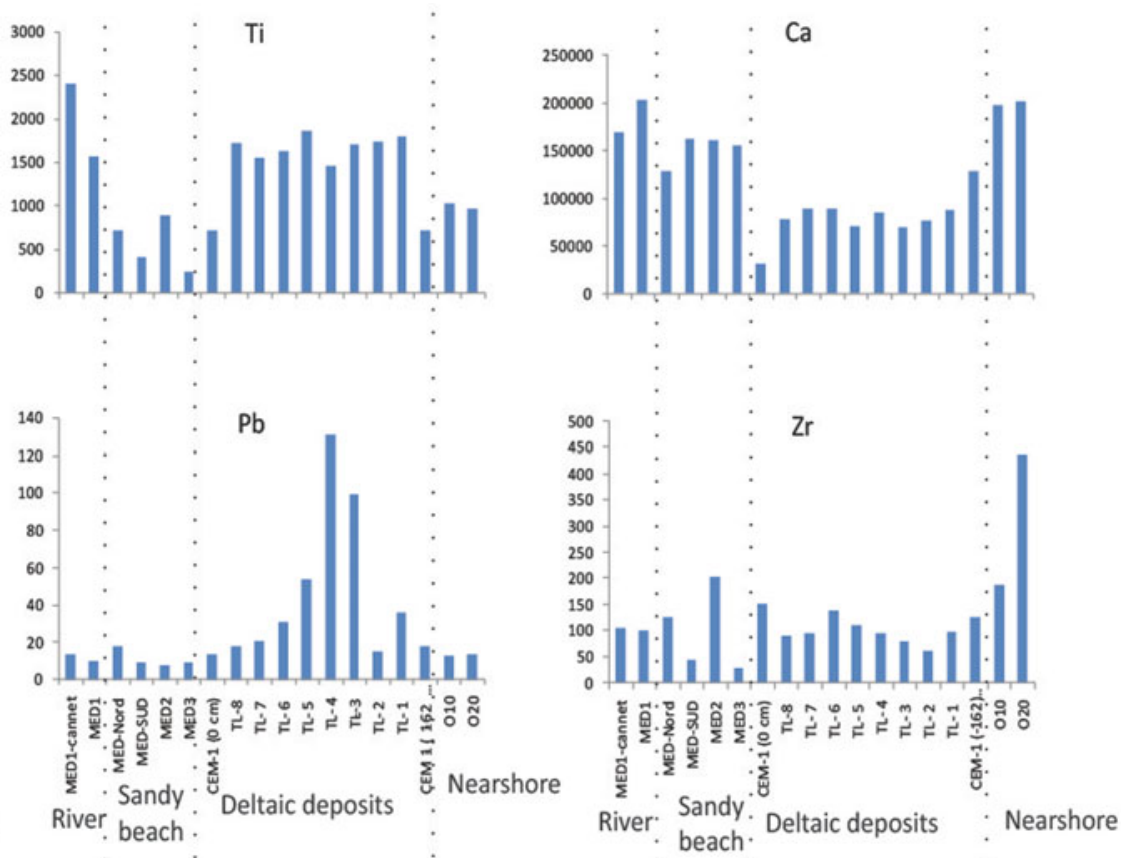

Fig. 2 The geochemical elements evolution of the Rubidium $(\mathrm{Rb})$, the Titanium $(\mathrm{Ti})$ the calcium $(\mathrm{Ca})$, the $\mathrm{Zinc}(\mathrm{Zn})$, the Lead $(\mathrm{Pb})$ and the Zerconium evolution in the sediments samples in the River, sandy beach, deltaic deposits and the nearshore of the Medjerda river coast 


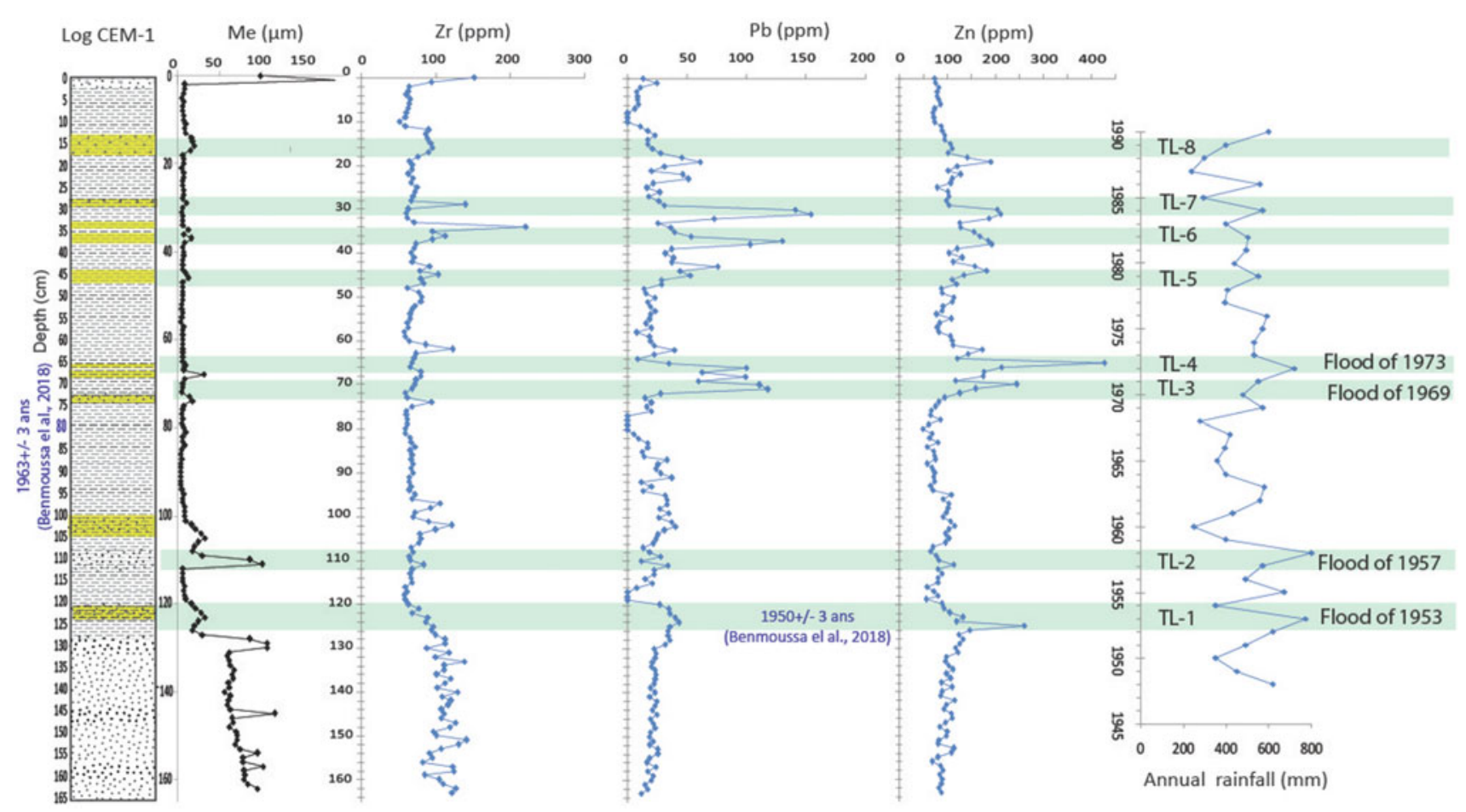

Fig. 3 The extreme floods identification based on litho stratigraphic log, median grain size (Me); geochemical elements concentration peaks and historical annual rainfall

important in the recent sandy beach (top of the CEM-1; $151.33 \mathrm{ppm})$ and the nearshore sediment (O10; $187.41 \mathrm{ppm}$ and $\mathrm{O} 20 ; 437.95 \mathrm{ppm})$. Finally, the $\mathrm{Ca}$ decreases from 200,346 in the nearshore sediment to $77,790 \mathrm{ppm}$ in the turbidity layers.

\section{Discussion}

The grain size analysis of surface samples reveals that the coarser deposits present in river consist of heterogeneous medium sand. The sediment of sand beach and the near shore deposits are characterized by unimodal grain size distribution with medium sand. The deltaic deposit is mostly represented of heterogeneous multimodal sediment. However, the turbidity layers are characterized by multimodal grain size distribution. They are formed by three main grain size facies (clay, silt and very fine sand). The geochemical analysis of the surface and core sediments shows that the marine sediments source is represented by $\mathrm{Ca}$ and $\mathrm{Zr}$ and particularly the basal sand of cores. The $\mathrm{Rb}$, $\mathrm{Ti}, \mathrm{Zn}$ and $\mathrm{Pb}$ constitute the terrestrial sediment source. Silt and clay are generally rich in terrigenous elements. The level peaks of ETM $(\mathrm{Pb}, \mathrm{Zn})$ are associated with fine terrestrial sediment (clay and silt). The strongly concentration of $\mathrm{Zr}$ is associated with turbidity layers and the surf zone deposits (O20). The $\mathrm{Zr}$ is generally associated with aeolian transport deposits [4]. $\mathrm{Zr}$ is a heavy metal that requires a strong dynamic energy to be mobilized in the coastal area. The multi proxy results (Fig. 3) reveal that the turbidity layers are characterized by terrestrial sediment source and strongly mining contamination of $\mathrm{Zn}$ and $\mathrm{Pb}$. Accordingly, we associate the turbidity layers with high floods events. Based on previous results of [5] completed by the historical annual rainfall, we associate the TL-1; TL-2; TL-3 and TL-4 to four exceptional floods of Medjerda (1953, 1957, 1969 and 1973) (Fig. 3). These events caused the leaching of old mining discharges into the Medjerda watershed responsible for the coastal sediment contamination of $\mathrm{Pb}$ and $\mathrm{Zn}$ since 1950 .

\section{Conclusion}

The terrestrial sediment which feeds the northern coast of the Gulf of Tunis is characterized by the very fine-grained sediment (clay and silt). The geochemical signature of the terrestrial sediment is characterized by highly concentration of $\mathrm{Rb}, \mathrm{Ti}, \mathrm{Zn}$ and $\mathrm{Pb}$. The Medjerda River is the mainly source of silts and clay sediment for the northern coast of the Gulf of Tunis. Even during high frequency events, the sediments are devoid of any coarse fraction. Besides, the mining pollution 
(i.e. $\mathrm{Zn}$ and $\mathrm{Pb}$ ) is relatively strong in the coastal area especially during the great floods episodes of watershed leaching of Medjerda River.

\section{References}

1. Flemming, B.W., Hansom, J.D.: Estuarine and coastal geology and geomorphology-A synthesis, In: Wolanski, E., McLusky, D.S. (eds.) Treatise on Estuarine and Coastal Science, vol. 3, pp. 1-5. Academic Press, Waltham (2011)

2. Syvitski. P.M., Kettner. A.: Sediment flux and the anthropocene. Phil. Trans. R. Soc. A 369, 957-975 (2011). https://doi.org/10. 1098/rsta.1010.0329
3. Croudace, I.W., Rindby, A., Rothwell, R.G.: ITRAX: description and evaluation of a new multi-function X-ray core scanner. Spec. Publ. Geol. Soc. Lond. 267, 51-63 (2006)

4. Affouri, A., Dezileau, L., Kallel, N.: Extreme flood events reconstruction during the last century in the $\mathrm{El} \mathrm{Bibane} \mathrm{lagoon}$ (Southeast of Tunisia): a multi-proxy approach, Clim. Past Discuss. (2016). https://doi.org/10.5194/cp-2016-40

5. Benmoussa, T., Amrouni, O., Dezileau, L., Mahe, G., Saâdi, A.: Impact of the Medjerda Sedimentary Fluxes on the Morphodynamic Equilibrium of the Northern Coast of the Gulf of Tunis (Medjerda-Raoued coast), PIAHS, vol. 377. Port Elizabeth, South Africa (2018). https://doi.org/10.5194/piahs-377-77-2018 